\title{
THE JOURNEY TO THE WEST
}

Volume 4

Translated and Edited by Anthony C. Yu

This is the fourth and final volume of the first complete English translation of $\mathrm{Hsi}_{-y u} \mathrm{Chi}$, a classic sixteenth-century epic that lies at the center of the historical Chinese cultural consciousness.

"Yu is utterly faithful as a translator and yet shows such a high regard for readability.... There can be no doubt that English literature will be permanently enriched by the assimilation of a foreign masterpiece of the first importance."-C. T. Hsia, New York Times Book Review

Cloth \$35.00 544 pages (est.) February

Also available

Volume 1 Cloth $\$ 30.00$ Paper $\$ 8.95$

Volume 2 Cloth $\$ 30.00$ Paper $\$ 9.95$

Volume 3 Cloth $\$ 30.00$

\section{2 by Derrida}

\section{MARGINS OF PHILOSOPHY}

Translated, with Additional Notes, by Alan Bass

In the present volume, Derrida restates not so much the limits as the margins of philosophy, as he examines in turn the thought of Saussure and Rousseau, Kant, Hegel, Nietzsche, Heidegger, Valéry, and others.

Cloth $\$ 25.00 \quad 358$ pages Available

\section{POSITIONS}

\section{Translated and Annotated by Alan Bass}

Derrida takes positions on his detractors, his supporters, and the two major preoccupations of French intellectual life, Marxism and psychoanalysis. The three interviews comprising this volume present a multifaceted picture of Derrida.

Paper $\$ 4.50122$ pages Available

\section{STUDIES IN}

\section{RELATIONAL GRAMMAR 1}

\section{Edited by David M. Perlmutter}

In this long-awaited book - the first in a projected two-volume work-

Perlmutter has co-authored and edited ten essays that introduce relational

grammar, a novel conception of sentence structure that offers far-reaching

conclusions for universal grammar.

Cloth \$ TBA 416 pages (est.) Available

\section{THIRTY MILLION}

\section{THEORIES OF GRAMMAR}

\section{James D. McCawley}

McCawley critiques Chomsky's "extended standard theory" and explores alternative positions on the issues discussed.

Cloth $\$ 20.00 \quad 240$ pages Available

\section{THE UNIVERSITY OF CHICAGO PRESS}




\section{SYMBOLISM AND INTERPRETATION BY TZVETAN TODOROV Translated by Catherine Porter}

"Like Todorov's earlier books this one is filled with brilliant critical insights and immense learning. Todorov has the gift, along with a mere handful of other commentators-Auerbach, Frye, Curtius, and Jakobson-to deal with large concepts of a very complex order in lucid and direct terms. It is astonishing to see with what ease Todorov wanders across a variety of disciplines and many centuries-from Greek antiquity to the present age -in the course of elucidating his theories on poetics and interpretation."-Melvin J. Friedman, University of Wisconsin. $\$ 19.50$

\section{And other books by Tzvetan Todorov... THEDRIES OF THE SYMBOL}

Translated by Catherine Porter. "Theories of the Symbol initiates a major methodological (re)turn: the move away from structuralistsemiotic tendencies to other forms of literary philosophy and history. It is the change of critical terrain which no doubt will direct us towards redefining and determining the future models of literary theory. On this point, Todorov is, as usual, ahead of the game."-Josué V. Harari, Modern Language Notes. \$22.50.

\section{THE POETICS OF PROSE}

Translated by Richard Howard. Foreword by Jonathan Culler. "A collection of 16 essays...the book can serve as an introduction to literary structuralism, an introduction unusually lucid and unmarred by the technical obscurantism of much recent structuralist criticism." -Choice. $\$ 22.50$ cloth; $\$ 6.95$ paper

\section{THE FANTASTIC}

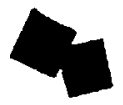

\section{A Structural Approach to a Literary Genre}

Translated by Richard Howard. "This work is much more than what its title might imply to an American reader. It is not simply another 'formalist' categorizing of a particular literary genre.... [It] is an important work for anyone interested in criticism in general or in the criticism of fiction in particular."-Choice. $\$ 4.95$ paper

\section{CORNELL UNIVERSTY PRESS}

P.O. Box 250, Ithaca, New York 14850 